AperTO - Archivio Istituzionale Open Access dell'Università di Torino

\title{
Thyroid Autoimmunity and Cancer
}

\section{This is a pre print version of the following article:}

Original Citation:

\section{Availability:}

This version is available http://hdl.handle.net/2318/1633825

since 2017-05-15T10:41:43Z

Publisher:

S. Karger AG

Published version:

DOI:10.1159/000452909

Terms of use:

Open Access

Anyone can freely access the full text of works made available as "Open Access". Works made available under a Creative Commons license can be used according to the terms and conditions of said license. Use of all other works requires consent of the right holder (author or publisher) if not exempted from copyright protection by the applicable law. 
This is the author's final version of the contribution published as:

Felicetti, Francesco; Catalano, Maria Graziella; Fortunati, Nicoletta. Thyroid Autoimmunity and Cancer. S. Karger AG. 2017. pp: 97-109.

in

\section{Frontiers of Hormone Research}

The publisher's version is available at:

https://www.karger.com/Article/Pdf/452909

When citing, please refer to the published version.

Link to this full text:

http://hdl.handle.net/2318/1633825 


\section{Thyroid Autoimmunity and Cancer}

\section{Francesco Felicetti $^{a}$, Maria Graziella Catalano ${ }^{b}$, Nicoletta Fortunati ${ }^{a}$}

${ }^{a}$ Oncological Endocrinology Unit, Città della Salute e della Scienza Hospital,

${ }^{\mathrm{b}}$ Department of Medical Science, University of Torino, Turin, Italy.

Corresponding Author

Dr Nicoletta Fortunati

Oncological Endocrinology Unit

Città della Salute e della Scienza Hospital

3 Via Genova, Turin 10126, Italy

E-mail: nfortunati@cittadellasalute.to.it 


\begin{abstract}
Cancer and autoimmune diseases are often associated in the same individual. The functional link between immune system and cancer development is only partially known. Even though the immune system can control the development of cancer through immune surveillance, cancer cell itself can escape immune surveillance. Actually, it is debated whether autoimmune diseases have to be regarded as cancer cause or its consequence.

In particular, autoimmune thyroiditis and thyroid cancer (in particular, papillary thyroid cancer) are a fascinating model of this complex relationship. In the present review, we describe what has been reported by now in literature about autoimmune thyroiditis and papillary thyroid cancer, and on the basis of available data, we try to clarify the present knowledge.
\end{abstract}




\section{Cancer and Immunity}

Cancer and immunity show multiple points of interplay. Their functional relationship is complex and the final outcome could be extremely different. All the various characters playing in the immune response are somehow involved in cancer, e.g. antigen presenting cells, antibodies, B-cells, T-cells, cytokines, etc. Linkage between cancer and immune system diseases is also known but its pathogenetic meaning is quite far to be fully understood.

The immune system is programmed to distinguish between self and non-self, in order to react against extraneous threat while avoiding immune reaction to self. However, when the mechanism of immune tolerance is somehow imbalanced, autoimmunity or cancer or even both can occur.

The immune system can control the development of cancer through immune surveillance, but, despite this, cancer cells can develop several strategies to escape immune surveillance. During cancer development, the innate immunity comprising antigen presenting cells such as dendritic cells and macrophages as well as natural killer cells become tolerant. Furthermore, $\mathrm{T}$ cells that constitute the adaptive immune response undergo apoptosis; the production of immunosuppressive cytokines, in addition, makes them unable to interact with antigen presenting cells. The result is an environment favorable to tumor outgrowth [1]. In more details, the balance/unbalance between cancer and immune cells results in three different scenarios: 1) elimination of tumor, 2) equilibrium; 3) escape immune surveillance (Figure 1). In the elimination phase, during early tumor development, cancer cells present tumor-specific antigens recognized by the immune system [2]. Inflammatory cytokines (e.g. IFN $\gamma$ and IL12) produced and released from tumor cells, surrounding stromal cells and macrophages, attract natural killer cells and induce maturation of dendritic cells that will be able to present tumor-associated antigens to $\mathrm{T}$ cells leading to the ultimate killing of tumor cells. In the equilibrium phase, the immune system through IFN $\gamma$-mediated cytotoxicity kills the highlyimmunogenic tumor cells but this may select clones of low-immunogenic cells that are more resistant to immune cell-mediated killing. This phase may last for a long time (months or years) and its final result could be either elimination of tumor cells or escape from immune surveillance [3]. Lastly, the escape phase is characterized by the development of cancer that becomes clinically evident. Cancer cells are able to produce highly immunosuppressive cytokines such as TGF $\beta$ and IL10 to inhibit T cell response and induce T cell 
apoptosis, to block dendritic cell maturation and, finally, to induce $\mathrm{T}$-regulatory ( $\mathrm{T}$ reg) cells that further suppress the immune system.

Cancer development is often concomitant with autoimmunity phenomena. A wide range of autoantibodies can be produced and detected in serum of different type of cancer patients. Antibodies can be directed against tumor-associated antigens (e.g. antibodies to oncoproteins or tumor suppression genes), or to antigens not directly associated to tumor (e.g. anti-nuclear and anti-thyroid antigens).

Cancer development after or together to autoimmune disease could be related to the prolonged and often severe immune stimulus of autoimmune disease. Moreover, paraneoplastic autoimmune disorders characterized by rheumatic manifestations can precede, accompany or follow the onset of tumor. It was also reported that paraneoplastic rheumatism could be the basis for symptoms of systemic autoimmune diseases [4]. Autoimmunity manifestations can be associated to haematologic malignancies, breast cancer, colon cancer, melanoma and thyroid cancer.

\section{Thyroid Cancer and AutoImmunity: Epidemiological and Clinical Overview}

The relationship between chronic inflammatory diseases and carcinogenesis has been widely investigated. Following the first hypothesis formulated by Wirchow at the end of XIX century, strong evidences were then collected linking up intestinal chronic inflammatory diseases and colorectal cancer, asbestosis and mesothelioma, chronic $\mathrm{HBV}$ or $\mathrm{HCV}$ infections and hepatocellular carcinoma, chronic obstructive pulmonary disease and lung cancer. Moreover, immune cells (tumor associated lymphocytes, tumorassociated macrophages, mast cells and dendritic cells) were identified within neoplastic lesions and recognized as determinant factors of tumor growth and tumor-induced immune tolerance $[5,6]$, as already reported.

Also, the association between autoimmune thyroid diseases (AITDs) and thyroid cancer (TC) has been widely debated in the last decades.

TC can arise both from follicular or parafollicular thyroid cells and represents the most frequent endocrine neoplasia. Three histotypes originate from follicular cells: well-differentiated (WDTC), poorly-differentiated 
(PDTC) and anaplastic (ATC) thyroid carcinoma. WDTC are categorized in papillary (PTC) and follicular carcinoma (FTC). The incidence of TC in the last decades is significantly increased, due to the increased number of WDTC diagnosed in the initial stadium. This observation seems to be confirmed by the stability of the mortality rate due to TC [7]. Medullary thyroid carcinoma (MTC), originating from parafollicular Ccells shows a different pathogenesis and, although sporadic in the majority of cases, in about $20 \%$ of cases is due to a germline mutation in the RET proto-oncogene in the contest of genetic syndromes (MEN2, FMTC). Instead, de novo RET/PTC translocations, BRAF, RAS, RET and TRKA mutations are the most frequently described in WDTC [8].

AITDs are a group of quite common pathological conditions with different clinical presentations, either hypothyroidism or hyperthyroidism, due to an immune system deregulation that leads to a T-cell mediated damage against the thyroid gland. Both the main types of AITDs, Hashimoto's Thyroiditis (HT) and Graves' Disease (GD), are characterized by lymphocytic infiltration of the parenchyma. The prevalence of AITDs is estimated to be about $5 \%$ in the general population, with a female/male ratio of $4-10 / 1$; the prevalence of thyroid auto-antibodies without clinical manifestations is probably higher [9]. Antibodies to thyroperoxidase (TPO-Ab) are considered the most sensitive serological marker of HT and probably they also have a correlation with the grade of lymphocyte infiltration within the thyroid gland [10]. Antibodies to thyroglobulin $(\mathrm{Tg}-\mathrm{Ab})$, although less sensitive and specific for the diagnosis of HT, have been hypothesize to reflect the initial immune response and, consequently, can be the only ones present in the early phase of the process [10]. TSH receptor antibodies (TRAb) are detectable in almost all cases of GD and responsible for the development of hyperthyroidism 9.

From an epidemiological perspective, female sex and iodine levels are key factors in the development of both AITDs and thyroid nodules [9].

Since Dailey et al [11] in 1955 firstly hypothesized the association between AITDs and TC, a high number of studies focused on this field have been published. HT was frequently associated with an increased incidence of PTC [12,13] but some studies showed contrasting results [14-16]. More controversial is the association between GD (and hyperthyroidism) and the onset of TC [17]. 
As recently underlined by Fiore et al in their review [16], different degrees of association were found if cytological or histological series were considered [18-20]. As hypothesized by the Authors themselves [19], this result could be strongly influenced by a selection bias: if cytological examination is usually performed in patients with ultrasound suspicious thyroid nodules (i.e. with high a priori probability of malignancy), thyroidectomy, instead, is frequently performed in patients with GD (to treat hyperthyroidism) or due to compressive symptoms in subjects with large nodular goiter and coexisting AITD.

Moreover, it should also be taken into account the heterogeneity in AITD definitions adopted in different studies, ranging from the presence of serum circulating thyroid antibodies with or without hypothyroidism to the presence of lymphocytic infiltration in the thyroid gland (also in the absence of thyroid antibodies) [16,]. Latrofa et al hypothesized that differences in the associations of these conditions with TC could be due to different epitope pattern of $\operatorname{TgAb}[21]$.

Chronic lymphocytic thyroid infiltration (CLTI) has been reported to be significantly higher in patients with PTC than in those with nodular goiter [20,22]. In term of prognosis, the final result of the complex interactions between immune system and tumor cell still remains debated. The presence of lymphocytes has been interpreted as an active immune host response or just as a coexisting condition. Accordingly, only few studies reported a worse prognosis of PTC associated with CLTI, but the great majority agree with the hypothesis that the presence of CTLI may lead to a better prognosis or not influence the clinical outcome of PTC $[6,13,17,23]$. Kim et al, in a study aimed to define the role of CLTI according to BRAF V600E mutation status in a cohort of PTC patients, concluded that CLTI was an independent predictor for low prevalence of both extra-thyroidal extension and central compartment nodal metastases, regardless BRAF mutation status [24]. Nevertheless, higher prevalence of multifocal or bilateral lesions was reported in TC patients with coexisting CLTI [24] and recently Iliadou el al [25] showed that children and adolescents with CLTI presented more frequently familial PTC, even if no differences in outcome were found with respect to the presence of CLTI. In this regard, it should finally be noted that TC histotypes with a worse prognosis (PDTC, ATC) are characterized by a very reduced lymphocyte infiltration [26].

The increased levels of thyroid stimulating hormone (TSH) have been hypothesized to be a different mechanism underlying the linkage between PTC and AITDs [27]. Indeed, hypothyroidism represents the 
most common clinical presentation of AITDs and TSH is the major growth factor for thyrocytes. Several studies demonstrated the close relationship between TSH serum levels and the risk of TC [28,29], and the association was confirmed for increasing TSH values but still within the reference ranges [29].

Even though controversial, literature about the linkage between AITDs and TC is wide, while the reports about a potential relationship between AITDs and MTC (or thyroidal C-cells hyperplasia) are nearly anecdotal and - beyond suggestions that can originate from small series or case reports - they do not allow to draw definitive conclusions [30].

\section{Thyroid Cancer and AutoImmunity: Cellular and Molecular Suggestions}

\section{Dendritic Cells (DCs)}

Either in PTC and in AITDs prominent leukocytic infiltration of thyroid tissue is present [24]. In HT the first step is infiltration of dendritic cells (DCs) and then of leucocytes. Actually, DCs are observed also in PTC, isolated in the background and/or in association with tumor cells [31].

DCs are believed to play a central role in autoimmune and neoplastic thyroid diseases. Generally speaking, DCs are of two different types: plasmacytoid DCs (pDCs) and myeloid DCs (mDCs); pDCs are the main source of IFNs and regulate $\mathrm{T}$ cells generation and function; mDCs mainly promote $\mathrm{T}$ helper function and induce IL-12 and IL-23 secretion [32].

As far as AITDs are concerned, pDCs are believed to have a specific role. Actually, DCs were reported to be increased in thyroid infiltrates in all main autoimmune thyroid diseases, as HT and GD. In particular, mature DCs were observed in connective tissue while immature DCs were mainly located around thyroid follicles. The evaluation of peripheral blood DC subpopulation in comparison to thyroid gland [33] evidenced that peripheral pDCs are significantly lower in autoimmune thyroid diseases than in healthy controls. Peripheral pDCs, in addition, are characterized by an increased in vitro IFN $\square$ production under stimulation. Thyroid DCs are indeed characterized by higher Fas ligand expression in comparison with peripheral pDCs.

It was claimed that molecules involved in chronic inflammation can also have a considerable function in tumor induction and development. DCs have also been proposed to participate in the development of thyroid cancer. In PTC rich DCs infiltrates were reported in all different histotypes [26]. DCs present a precise 
distribution in tumors; immature DCs are generally located within PTC nodules, while mature DCs are observed around tumor [31,34]. It is still controversial whether DCs are linked to a better or worst prognosis of PTC. It was suggested that the extent of DC infiltrate in PTC is positively associated with favorable clinical course [35]. From the other hand, observation by other Authors pointed out that short-term diseasefree survival while correlating positively with thyroiditis grade did not with the number of infiltrating DCs [36]. It was therefore suggested that DCs recovered in PTC do not have any defensive action, but could be involved in tumor immune escape process. DCs are, therefore, for sure involved in PTC, but their precise role and significance still have to be elucidated.

\section{Cellular and Humoral Immune Response}

The autoimmune process starts in thyroiditis with DC infiltration followed by additional leucocytes; as already mentioned, DCs were observed also in PTC, either in the background and/or close to tumor cells [31] and their presence can account for further immune cell infiltration. In thyroid the presence of leukocyte infiltration constituted by $\mathrm{T}$ and, B cells, macrophages, and Th17 cells was reported to be associated to a better prognosis in PTC patients $[17,23]$. On the contrary, poor prognosis was related to the absence in PTC nodules of immune-stimulating cells such as CD83-positive mature leucocytes and activated DCs [34]. Divergent reports, however, have to be mentioned. In fact, the presence in PTC and metastatic nodes of T cells, macrophages, pDCs, and $\mathrm{T}$ reg cells was associated to increased tumor progression, invasion, node metastasis, and an overall decreased cancer-related survival [37].

The relationship between thyroid immunity and tumor development is, therefore, pretty intricate. Which between the two is the cause and which the consequence of the other has definitely not yet been clarified.

Since PTC and HT can be synchronous, it was suggested that the neoplasia could be induced by inflammation. It was suggested that patients with prolonged exposure to inflammation have a higher risk to develop cancer [38]. This hypothesis is supported by several observations. Higher concentrations of proinflammatory cytokines with growth factor activity (e.g., IL-17, IFN- $\square$, and TNF- $\square$. were observed in 
thyroiditis [39]. Furthermore, thyroid cells possess hydrogen peroxide $\left(\mathrm{H}_{2} \mathrm{O}_{2}\right)$, one of the naturally occurring reactive oxygen species (ROS). ROS have an interesting role being able to induce DNA damage and promote the epithelial to mesenchymal transition [40]. Inflammation can imbalance between neutralized and unneutralized $\mathrm{H}_{2} \mathrm{O}_{2}$, supporting the hypothesis of ROS-dependent inflammation-induced thyroid cancer. Last, less destructive thyroiditis (euthyroid, or not fully hypothyroid) seems to have a higher risk for PTC than destructive thyroiditis [38].

Since in PTC immune cell infiltration was related to a better prognosis, the existence of antitumor immune response was suggested. This could be also supported by the observation that approximately twofold higher concentration of anti-Tg and anti-TPO antibodies can be found in the peripheral blood of PTC patients compared to the general population [41]. The induced antitumor immune response should be due to the presence of papillary thyroid microcarcinomas that share with PTC a similar gene expression profile [42].

Any alteration of the immune system capacity to distinguish between self and non-self antigens may result either in autoimmunity or in cancer. PTC is able to trigger a number of immune-escape mechanisms that correlate with its aggressiveness. It was reported that thyroid tumor cells upregulate cytokines such as IL-4 and IL-10 [43]. IL-4 reduces the proliferation and impairs the function of cytotoxic CD8+ T cells. PTCderived DCs favor the differentiation of CD4+ $\mathrm{T}$ cells into $\mathrm{T}$ reg cells [44] that are increased in more aggressive PTC and node metastasis [37]. T reg cells are able to suppress NK cell functions. Moreover, specific surface molecules could be involved in tumor growth despite the immune response. As far as humoral immune response is concerned, elevated anti-TPO antibodies were suggested to have a protecting role in patients with thyroiditis [38], while anti-Tg antibodies could be a risk factor for PTC [45].

\section{Iodine, autoimmunity and cancer}

Iodine intake is a primary determinant of thyroid disorders. As reported above, iodine intake is a primary determinant of thyroid disorders; in contrast, its role in thyroid cancer is still debated. HT appears to be worsened by iodine intake [46]; in fact, increased levels of thyroid antibodies result after iodine replacement 
[47]. The proposed mechanism is an increase in thyroglobulin immunogenicity, as a consequence of the presentation of a cryptic pathogenic peptide induced by iodination [48].

As far as the role of iodine in thyroid cancer is concerned, several authors suggest that iodine intake may contribute to PTC increased incidence observed in countries with iodized salt programs [49]; others report that thyroid cancer is linked to iodine deficiency, as the incidence of thyroid cancer is higher in nodular goiter [50]. Animal studies suggest that iodine deficiency can favor thyroid carcinogenesis [51]; on the contrary, iodine excess appears to be a weak promoter [52]. However, most of the studies were conducted by inducing profound iodine deficiency and excess more severe than those found in human diets.

As far as studies in humans are concerned, they mainly deal with the effect of salt iodization introduction or level increase on the PTC/FTC ratio, and on the percentage of anaplastic thyroid cancer. They report an increase in the PTC/FTC ratio [53], and a decrease of ATC [54].

\section{Genetic alterations}

Genetic alterations may represent a link explaining the coexistence between PTC and thyroid autoimmune diseases.

Molecular studies have shown that RET/PTC rearrangements occur in 3-60\% of PTC cases with an overall prevalence depending on geographic factors and radiation exposure [55]. They are the result of the fusion of the RET tyrosine kinase domain with the N-terminals of other genes (H4/CCD6 in RET/PCT1; RFG/NCOA4 in RET/PTC3). The rearrangement determines the ligand-independent activation of the tyrosine kinase domain and results in the increased expression of genes involved in proliferation and survival. RET/PTC rearrangements are present in about $90 \%$ of AITDs [56]; patients exposed to radiation from the Chernobyl nuclear disaster often develops RET/PTC induced papillary tumors associated with autoimmune thyroiditis [57]; finally, transgenic mice engineered to express RET/PTC develop papillary carcinomas and chronic thyroiditis [58]. Two different hypothesis support the role of RET/PTC as a link between PTC and autoimmune thyroiditis. The first theory is that oncogenes responsible for cell neoplastic transformation elicit an inflammatory pro-tumorigenic microenvironment. In fact, Borello et al [59] demonstrated that RET/PTC1 oncogene, when exogenously expressed in primary normal human thyrocytes, 
induces the expression of a large set of genes involved in inflammation and tumor invasion, including chemokines (CCL2, CCL20, CXCL8, and CXCL12), chemokine receptors (CXCR4), cytokines (IL1B, CSF1, GM-CSF, and G-CSF), matrix-degrading enzymes (metalloproteases and urokinase-type plasminogen activator and its receptor), and adhesion molecules (L-selectin). In this context, other authors demonstrated that RET/PTC3-thyrocytes express high levels of pro-inflammatory cytokines and proteins involved in the immune response [60] suggesting that RET/PTC oncoproteins may be directly involved in the early modulation of the immune response and may account for the chronic inflammatory infiltrates and chronic inflammatory thyroiditis, which can be observed in 20-50\% of PTC cases. Moreover, gene expression studies in cellular systems showed that not only RET/PTC but also RAS and BRAF proteins, all belonging to the RET-PTC/RAS/BRAF/ERK pathway, and whose mutations are present in FTC and PTC, are able to induce the up-regulation of chemokines, which in turn could contribute to neoplastic proliferation, survival and migration [61].

The second hypothesis is that that inflammation might facilitate the RET/PTC rearrangement. According to this hypothesis, free radical production, cytokine secretion, cellular proliferation as well as other phenomena related to inflammation might predispose to the rearrangement in follicular cells. Based on the results of these studies, a link between a transforming human oncogene, inflammation, and malignant behavior has been suggested. However, other studies disagree about the meaning of this link. Nikiforova and colleagues showed that RET/PTC rearrangements were detected only in PTC not associated with thyroiditis [62]. Rhoden and colleagues reported that only few follicular cells, expressing very low levels of RET/PTC, were detected in Hashimoto's thyroiditis, thus suggesting that RET/PTC expression does not necessarily predicts the development of a PTC in patients with thyroiditis [63].

Beyond RET/PTC, other gene alterations have been suggested as links between thyroid cancer and autoimmune thyroiditis. Unger et al [64] demonstrated that p63 protein was commonly expressed in PTC and in Hashimoto's thyroiditis. p63 regulates the stem cell phenotype in squamous epithelia and it is strongly expressed in the basal layer, the stem cell reservoir of squamous epithelia [65]. Authors suggested that p63 expression may be a potential pathobiologic link between the two disorders. 
Larson et al [66] demonstrated a 43.8\% incidence of autoimmune thyroiditis and associated WTDC. As the PI3K/Akt pathway plays a critical role in the balance between cell survival and apoptosis and the inflammatory response by activating chemokine receptors and promoting leukocyte migration, authors evaluated the role of the PI3K/Akt pathway in autoimmune thyroiditis and associated cancer. As they observed increased p-Akt, Akt1 and Akt2 expression in areas of thyroiditis and thyroid cancer compared to normal surrounding thyroid tissue, they suggested a possible molecular mechanism involving PI3K/Akt in the link between HT and WTDC.

\section{Microchimerism}

The presence in the same organism of cells derived from two different individuals is known as "microchimerism", a phenomenon which primarily occurs during pregnancy. The passage of cells from the fetus to the mother is called fetal cell microchimerism (FCM), whereas that occurring from the mother to the fetus is named maternal cell microchimerism (MCM). As autoimmune thyroiditis appears to improve during pregnancy and to worsen after childbirth [67], several studies focused on FMC in AITDs. Klintschar et al. [68] demonstrated the presence of FMC in HT patients and intrathyroidal FMC were detected in GD [69]. Nevertheless, other authors failed to demonstrate and association between microchimerism and thyroid autoimmunity [70].

As well, FMC has been studied in thyroid cancer. Cirello et al [71] detected FMC in $47.5 \%$ of PTC of women with a previous male pregnancy; being FMC cells more represented in the tumor tissue with respect to normal section. Interestingly, FMC of both tumor and normal tissues expressed thyroglobulin, whereas only FMC present in the tumor tissue stained with CD45, a marker of hemopoyetic cells. Finally, to identify their function, authors stained $\mathrm{Tg}+$ and CD45+ cells for the major histocompatibility complex II (MHCII), which is a marker of antigen-presenting cells. Both $\mathrm{Tg}+$ and CD45+ male cells resulted negative for MHCII antigens; therefore, authors concluded that that $\mathrm{Tg}+\mathrm{MHCII}-$ male cells could have a role in tissue repair and that CD45+/MHCII- male cells could be NK cells with a role in the initiation of a cytotoxic reaction toward maternal malignant cells, on the whole indicating a protective role of microchimerism in thyroid cancer. Nevertheless, a possible causative role of FMC in thyroid cancer cannot be excluded, as CD45+/MHCII- 
male cells could alternatively be tumors associated macrophages, whose density is considered a marker of decreased survival in thyroid cancer [72].

\section{Conclusions}

Even though we are totally aware of the pathogenetic relationship between autoimmune thyroiditis and PTC, despite the bulk of information that has been accumulating over the last decade, our knowledge about the involved mechanisms and the flow direction (thyroiditis towards tumor or tumor towards thyroiditis or tumor and thyroiditis) is still poor. Many characters are playing in both pieces, as reported in Figure 2, but no final has been written yet. We look forward to future enlightening about the interplay between PTC and AITDs that could be the rational to design an accurate immunotherapy of thyroid cancer. 


\section{References}

1) Vinay DS, Ryan EP, Pawelec G, Talib WH, Stagg J, Elkord E, Lichtor T, Decker WK, Whelan RL, Kumara HM, Signori E, Honoki K, Georgakilas AG, Amin A, Helferich WG, Boosani CS, Guha G, Ciriolo MR, Chen S, Mohammed SI, Azmi AS, Keith WN, Bilsland A, Bhakta D, Halicka D, Fujii H, Aquilano K, Ashraf SS, Nowsheen S, Yang X, Choi BK, Kwon BS: Immune evasion in cancer: Mechanistic basis and therapeutic strategies. Semin Cancer Biol 2015; S185-98.

2) Vesely MD, Kershaw MH, Schreiber RD, Smyth MJ: Natural innate and adaptive immunity to cancer. Annu Rev Immunol 2011; 29:235-71.

3) Kim R, Emi M, Tanabe K: Cancer immunoediting from immune surveillance to immune escape. Immunology 2007; 121(1):1-14.

4) Mandal S, Pile K, Chacko RT, Danda D: Malignancy and autoimmunity: causally or casually related? International Journal of Rheumatic Diseases 2014; 17: 601-605.

5) Balkwill F, Mantovani A: Inflammation and cancer: back to Virchow? Lancet 2010; 357:539-545.

6) Guarino V, Castellone MD, Avilla E, Melillo RM: Thyroid Cancer and Inflammation. Molecular and cellular endocrinology 2010; 321:94-102.

7) Haugen BR, Alexander EK, Bible KC, Doherty GM, Mandel SJ, Nikiforov EY, Pacini F, Randolph GW, Sawka AM, Schlumberger M, Schuff K, Sherman SI, Sosa, JA, Steward DL, Tuttle RM, Wartofsky L. American Thyroid Association Management Guidelines for Adult Patients with Thyroid Nodules and Differentiated Thyroid Cancer. Thyroid 2015 Oct 14 DOI: 10.1089/thy.2015.0020 [Epub ahead of print]

8) Sippel RS1, Kunnimalaiyaan M, Chen H: Current management of medullary thyroid cancer. Oncologist 2008; 13(5):539-547.

9) Antonelli A, Ferrari SM, Corrado A, Di Domenicantonio A, Fallahi P: Autoimmune thyroid disorders. Autoimmunity Reviews 2015; 14:174-180.

10) Caturegli P, De Remigis A, Rose NR: Hashimoto thyroiditis: Clinical and diagnostic criteria. Autoimunnity reviews 2014; 13:391-397.

11) Dailey ME, Lindsay S, Skahen R: Relation of thyroid neoplasms to Hashimoto disease of the thyroid gland. AMA Arch Surg 1955; 70:291-297.

12) Okayasu I, Fujiwara M, Hara Y, Tanaka Y, Rose NR: Association of chronic lymphocytic thyroiditis and thyroid papillary carcinoma. A study of surgical cases among Japanese, and white and African Americans. Cancer 1995; 76: 2312-2318.

13) Kebebew E1, Treseler PA, Ituarte PH, Clark $\mathrm{OH}$ : Coexisting chronic lymphocytic thyroiditis and papillary thyroid cancer revisited. World J Surg 2001; 25(5):632-637.

14) Holm LE, Blomgren H, Löwhagen T: Cancer risks in patients with chronic lymphocytic thyroiditis. N Engl J Med 1985; 312(10):601-604.

15) Muzza M, Degl'Innocenti D, Colombo C, Perrino M, Ravasi E, Rossi S, Cirello V, Beck-Peccoz P, Borrello MG, Fugazzola L: The tight relationship between papillary thyroid cancer, autoimmunity and inflammation: clinical and molecular studies. Clinical Endocrinology (Oxford) 2010; 72:702708.

16) Fiore E, Latrofa F, Vitti P: Iodine, Thyroid Autoimmunity and Cancer. Eur Thyroid J 2015; 4:26-35.

17) Cunha LL, Ferreira RC, Marcello MA, Vassallo J, Ward LS: Clinical and pathological implications of concurrent autoimmune thyroid disorders and papillary thyroid cancer. J Thyroid Res 2011; 2011:387062. 
18) Boi F, Lai ML, Marziani B, Minerba L, Faa G,Mariotti S: High prevalence of suspicious cytology in thyroid nodules associated with positive thyroid autoantibodies. Eur J Endocrinol 2005; 153:637642.

19) Jankovic B, Le KT, Hershman JM: Clinical review: Hashimoto's thyroiditis and papillary thyroid carcinoma: is there a correlation? J Clin Endocrinol Metab 2013; 98:474-482.

20) Castagna MG, Belardini V, Memmo S, Maino F, Di Santo A, Toti P, Carli AF, Caruso G, Pacini F: Nodules in autoimmune thyroiditis are associated with increased risk of thyroid cancer in surgical series but not in cytological series: evidence for selection bias. J Clin Endocrinol Metab 2014; 99:3193-3198.

21) Latrofa F, Ricci D, Vitti P, Prinzis A, Cambuli VM, Ghiani M, Pilia S, Carta D, Loche S, Pinchera A, Mariotti S: Characterization of thyroglobulin epitopes in Sardinian adults and juveniles with Hashimoto's thyroiditis: evidence against a major effect of age and genetic background on B-cell epitopes. Clin Endocrinol (Oxf) 2010; 73:110-113.

22) Latrofa F, Ricci D, Montanelli L, Rocchi R, Piaggi P, Sisti E, Grasso L, Basolo F, Ugolini C, Pinchera A, Vitti P: Lymphocytic thyroiditis on histology correlates with serum thyroglobulin autoantibodies in patients with papillary thyroid carcinoma: impact on detection of serum thyroglobulin. J Clin Endocrinol Metab 2012; 97:2380-2387.

23) Ehlers M, Schott M. Hashimoto's thyroiditis and papillary thyroid cancer: are they immunologically linked? Trends Endocrinol Metab 2014; 25(12):656-564.

24) Kim SK, Woo JW, Lee JH, Park I, Choe JH, Kim JH, Kim JS: Chronic lymphocytic thyroiditis and BRAF V600E in papillary thyroid carcinoma. Endocr Relat Cancer 2016; 23(1):27-34.

25) Iliadou PK, Effraimidis G, Konstantinos M, Grigorios P, Mitsakis P, Patakiouta F, PazaitouPanayiotou K: Chronic lymphocytic thyroiditis is associated with invasive characteristics of differentiated thyroid carcinoma in children and adolescents. Eur J Endocrinol 2015; 173(6):827833.

26) Ugolini C, Basolo F, Proietti A, Vitti P, Elisei R, Miccoli P, Toniolo A: Lymphocyte and immature dendritic cell infiltrates in differentiated, poorly differentiated, and undifferentiated thyroid carcinoma. Thyroid 2007; 17:389-393.

27) Fiore E, Rago T, Latrofa F, Provenzale MA, Piaggi P, Delitala A, Scutari M, Basolo F, Di Coscio G, Grasso L, Pinchera A, Vitti P: Hashimoto's thyroiditis is associated with papillary thyroid carcinoma: role of TSH and of treatment with L -thyroxine. Endocr Relat Cancer 2011; 18: 429-437.

28) Polyzos SA, Kappaita M, Efstathiadou Z, Poulakos P, Slavakis A, Sofianou D, Flaris N, Leontsini M, Kourtis A, Avramidis A: Serum thyrotropin concentration as a biochemical predictor of thyroid malignancy in patients presenting with thyroid nodules. J Cancer Res Clin Oncol 2008; 134: $953-$ 960.

29) McLeod DS, Watters KF, Carpenter AD, Ladenson PW, Cooper DS, Ding EL: Thyrotropin and thyroid cancer diagnosis: a systematic review and dose-response meta-analysis. J Clin Endocrinol Metab 2012; 97(8):2682-2692

30) Zayed AA, Ali MK, Jaber OI, Suleiman MJ, Ashhab AA, Al Shweiat WM, Momani MS, Shomaf M, AbuRuz SM: Is Hashimoto's thyroiditis a risk factor for medullary thyroid carcinoma? Our experience and a literature review. Endocrine 2015; 48(2):629-636.

31) Pusztaszeri MP, Sadow PM, Faquin WC: Association of CD1a-positive dendritic cells with papillary thyroid carcinoma in thyroid fine-needle aspirations: a cytologic and immunocytochemical evaluation. Cancer Cytopathol 2013; 4:206-213.

32) Lewinski A, Sliwka PW, Stasiolek M: Dendritic cells in autoimmune disorders and cancer of the thyroid. Folia Histichim Cytobiol 2014; 52:18-28. 
33) Leskela S, Rodríguez-Muñoz A, de la Fuente H, Figueroa-Vega N, Bonay P, Martín P, Serrano A, Sánchez-Madrid F, González-Amaro R, Marazuela M :Plasmacytoid dendritic cells in patients with autoimmune thyroid disease. J Clin Endocrin Metab 2013; 98:2822-2833.

34) Xu WC, Li ZB, Chen YR, Li XT, Huang JX, Li YG, Chen SR: Expression and distribution of S-100, CD83, and costimulatory molecules (CD80 and CD86) in tissues of thyroid papillary carcinoma. Cancer Invest 2013; 29:286-292.

35) Batistatou A, Zolota V, Scopa CD: S-100 protein+ dendritic cells and CD34+ dendritic interstitial cells in thyroid lesions. Endocr Pathol 2002; 13:111-115.

36) Hilly O, Koren R, Raz R, Rath-Wolfson L, Mizrachi A, Hamzany Y, Bachar G, Shpitzer T: The role of S100-positive dendritic cells in the prognosis of papillary thyroid carcinoma. Am J Clin Pathol 2013; 139:87-92.

37) French JD, Kotnis GR, Said S, Raeburn CD, McIntyre RC Jr, Klopper JP, Haugen BR: Programmed death-1+ T cells and regulatory $T$ cells are enriched in tumor-involved lymph nodes and associated with aggressive features in papillary thyroid cancer. J Clin Endocrinol Metab 2012; 97(6), E934E943.

38) Paparodis R, Imam S, Todorova-Koteva K, Staii A, Jaume JC: Hashimoto's thyroiditis pathology and risk for thyroid cancer. Thyroid 2014; 7:1107-1114.

39) Landskron G, De la Fuente M, Thuwajit P, Thuwajit C, Hermoso MA: Chronic inflammation and cytokines in the tumor microenvironment. J Immunol Res 2014; 2014:149-185

40) Wang Z, Li Y, Sarkar FH: Signaling mechanism(s) of reactive oxygen species in EpithelialMesenchymal Transition reminiscent of cancer stem cells in tumor progression. Curr Stem Cell Res Ther 2010; 1:74-80.

41) Spencer CA: Clinical review: clinical utility of thyroglobulin antibody ( $\mathrm{TgAb})$ measurements for patients with differentiated thyroid cancers (DTC). J Clin Endocrinol Metab 2011; 12:3615-3627.

42) Kim HY, Park WY, Lee KE, Park WS, Chung YS, Cho SJ, Youn YK: Comparative analysis of gene expression profiles of papillary thyroid microcarcinoma and papillary thyroid carcinoma. J Cancer Res Ther 2010; 4:452-457.

43) Todaro M, Zerilli M, Ricci-Vitiani L, Bini M, Perez Alea M, Maria Florena A, Miceli L, Condorelli G, Bonventre S, Di Gesù G, De Maria R, Stassi G: Autocrine production of interleukin-4 and interleukin-10 is required for survival and growth of thyroid cancer cells. Cancer Res 2006; 66(3):1491-1499.

44) Yu H, Huang X, Liu X, Jin H, Zhang G, Zhang Q, Yu J: Regulatory T cells and plasmacytoid dendritic cells contribute to the immune escape of papillary thyroid cancer coexisting with multinodular non-toxic goiter. Endocrine 2013; 1:172-181.

45) Vasileiadis I, Boutzios G, Charitoudis G, Koukoulioti E, Karatzas T: Thyroglobulin antibodies could be a potential predictive marker for papillary thyroid carcinoma. Ann Surg Oncol 2014; 8:27252732.

46) Laurberg P, Bülow Pedersen I, Knudsen N, Ovesen L, Andersen S: Environmental iodine intake affects the type of nonmalignant thyroid disease. Thyroid 2001; 11:457-469.

47) Pedersen IB, Knudsen N, Carlé A, Vejbjerg P, Jorgensen T, Perrild H, Ovesen L, Rasmussen LB, Laurberg P: A cautious iodization program bringing iodine intake to a low recommended level is associated with an increase in the prevalence of thyroid autoantibodies in the population. Clin Endocrinol (Oxf) 2011; 75:120-126.

48) Latrofa F, Fiore E, Rago T, Antonangeli L, Montanelli L, Ricci D, Provenzale MA, Scutari M, Frigeri M, Tonacchera M, Vitti P: Iodine contributes to thyroid autoimmunity in humans by unmasking a cryptic epitope on thyroglobulin. J Clin Endocrinol Metab 2013; 98:E1768-E1774.

49) Global Iodine Nutrition Scorecard 2014. Available at: http://www.ign.org/cm_data/Scorecard_IGN_website_02_03_2015.pdf 
50) Cole WH, Majarakis JD, Slaughter DP: Incidence of carcinoma of the thyroid in nodular goiter. J Clin Endocrinol Metab 1949; 9:1007-1011.

51) Schaller Jr RT, Stevenson JK: Development of carcinoma of the thyroid in iodine-deficient mice. Cancer 1966; 19:1063-1080.

52) Boltze C, Brabant G, Dralle H, Gerlach R, Roessner A, Hoang-Vu C: Radiation induced thyroid carcinogenesis as a function of time and dietary iodine supply: An in vivo model of tumorigenesis in the rat. Endocrinology 2002; 143:2584-2592.

53) Huszno B1, Szybiński Z, Przybylik-Mazurek E, Stachura J, Trofimiuk M, Buziak-Bereza M, Gołkowski F, Pantoflinski J: Influence of iodine deficiency and iodine prophylaxis on thyroid cancer histotypes and incidence in endemic goiter area. J Endocrinol Invest 2003; 26:71-76.

54) Dong W1, Zhang H, Zhang P, Li X, He L, Wang Z, Liu Y: The changing incidence of thyroid carcinoma in Shenyang, China before and after universal salt iodization. Med Sci Monit 2013; 19:49-53.

55) Nikiforov YE: RET/PTC rearrangement in thyroid tumors. Endocr Pathol 2002; 13:3-16.

56) Wirtschafter A, Schmidt R, Rosen D, Kundu N, Santoro M, Fusco A, Multhaupt H, Atkins JP, Rosen MR, Keane WM, Rothstein JL: Expression of the RET/PTC fusion gene as a marker for papillary carcinoma in Hashimoto's thyroiditis. Laryngoscope 1997; 107:95-100.

57) Williams D: Cancer after nuclear fallout: lessons from the Chernobyl accident. Nat Rev Cancer $2002 ; 2: 543-549$.

58) Powell DJ Jr, Russell J, Nibu K, Li G, Rhee E, Liao M, Goldstein M, Keane WM, Santoro M, Fusco A, Rothstein JL: The RET/PTC3 oncogene: metastatic solid-type papillary carcinomas in murine thyroids. Cancer Res 1998; 58: 5523-5528.

59) Borrello MG, Alberti L, Fischer A, Degl'innocenti D, Ferrario C, Gariboldi M, Marchesi F, Allavena P, Greco A, Collini P, Pilotti S, Cassinelli G, Bressan P, Fugazzola L, Mantovani A, Pierotti MA: Induction of a proinflammatory program in normal human thyrocytes by the RET/PTC1 oncogene. Proc Natl Acad Sci USA 2005; 102:14825-14830.

60) Russell JP1, Shinohara S, Melillo RM, Castellone MD, Santoro M, Rothstein JL: Tyrosine kinase oncoprotein, RET/PTC3, indices the secretion of myeloid growth and chemotactic factors. Oncogene $2003 ; 22: 4569-4577$.

61) Melillo RM1, Castellone MD, Guarino V, De Falco V, Cirafici AM, Salvatore G, Caiazzo F, Basolo F, Giannini R, Kruhoffer M, Orntoft T, Fusco A, Santoro M: The RET/PTC-RAS-BRAF linear signaling cascade mediates the motile and mitogenic phenotype of thyroid cancer cells. Journal of Clinical Investigation 2005; 115:1068-1081.

62) Nikiforova MN, Caudill CM, Biddinger P, Nikiforov YE: Prevalence of RET/PTC rearrangements in Hashimoto's thyroiditis and papillary thyroid carcinomas. Int J Surg Pathol 2002; 10:15-22.

63) Rhoden KJ, Unger K, Salvatore G, Yilmaz Y, Vovk V, Chiappetta G, Qumsiyeh MB, Rothstein JL, Fusco A, Santoro M, Zitzelsberger H, Tallini G: RET/papillary thyroid cancer rearrangement in nonneoplastic thyrocytes: follicular cells of Hashimoto's thyroiditis share low-level recombination events with a subset of papillary carcinoma. J Clin Endocrinol Metab 2006; 91: 2414-2423.

64) Unger P, Ewart M, Wang BY, Gan L, Kohtz DS, Burstein DE: Expression of p63 in papillary thyroid carcinoma and in Hashimoto's thyroiditis: a pathobiologic link? Hum Pathol 2003; 34(8):764-769.

65) Pellegrini G, Dellambra E, Golisano O, Martinelli E, Fantozzi I, Bondanza S, Ponzin D, McKeon F, De Luca M: p63 identifies keratinocyte stem cells. Proc Natl Acad Sci USA 2001; 98:3156-3161. 
66) Larson SD, Jackson LN, Riall TS, Uchida T, Thomas RP, Qiu S, Evers BM: Increased incidence of well-differentiated thyroid cancer associated with Hashimoto thyroiditis and the role of the PI3k/Akt pathway. J Am Coll Surg 2007; 204:764-773.

67) Weetman AP: Immunity, thyroid function and pregnancy: molecular mechanisms. Nat Rev Endocrinol 2010; 6:311-318

68) Klintschar M, Immel UD, Kehlen A, Schwaiger P, Mustafa T, Mannweiler S, Regauer S, Kleiber M, Hoang-Vu C: Fetal microchimerism in Hashimoto's thyroiditis: a quantitative approach. Eur J Endocrinol 2006; 154:237-241

69) Ando T, Imaizumi M, Graves PN, Unger P, Davies TF: Intrathyroidal fetal microchimerism in Graves' disease. J Clin Endocrinol Metab 2002; 87:3315-3320.

70) Sgarbi JA, Kasamatsu TS, Matsumura LK, Maciel RMB: Parity is not related to autoimmune thyroid disease in a population-based study of Japanese-Brazilians. Thyroid 2010; 20:1151-1156.

71) Cirello V, Recalcati MP, Muzza M, Rossi S, Perrino M, Vicentini L, Beck-Peccoz P, Finelli P, Fugazzola L: Fetal cell microchimerism in papillary thyroid cancer: a possible role in tumor damage and tissue repair. Cancer Res 2008; 68:8482-8488.

72) Ryder M, Ghossein RA, Ricarte-Filho JC, Knauf JA, Fagin JA: Increased density of tumorassociated macrophages is associated with decreased survival in advanced thyroid cancer. Endocr Relat Cancer 2008; 15:1069-1074. 
Figure 1 - Cancer and Immune System: from Immuno Surveillance to Immune Escape

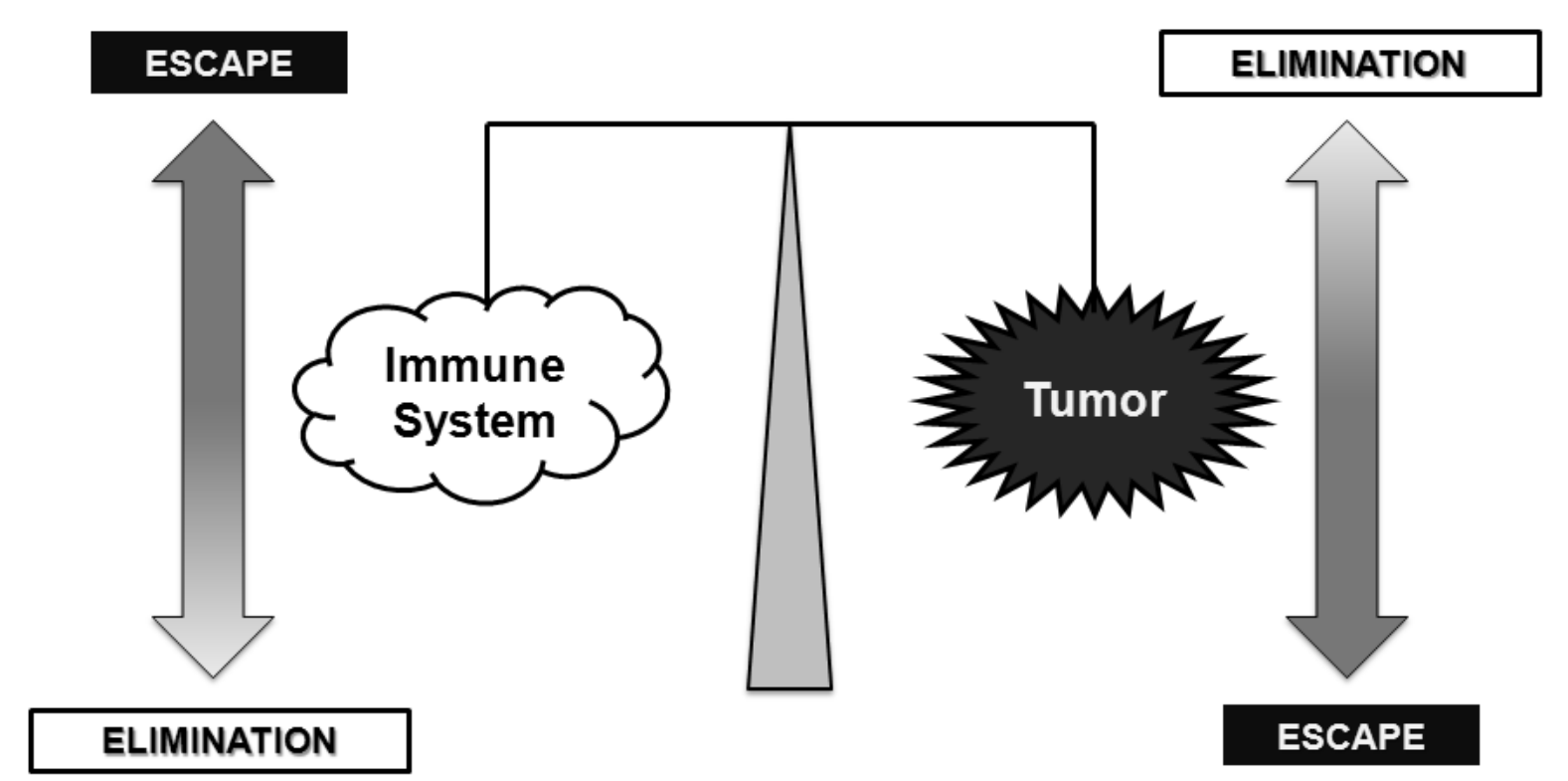


Figure 2 - Autoimmune Thyroiditis and Papillary Thyroid Cancer: cellular and molecular characters

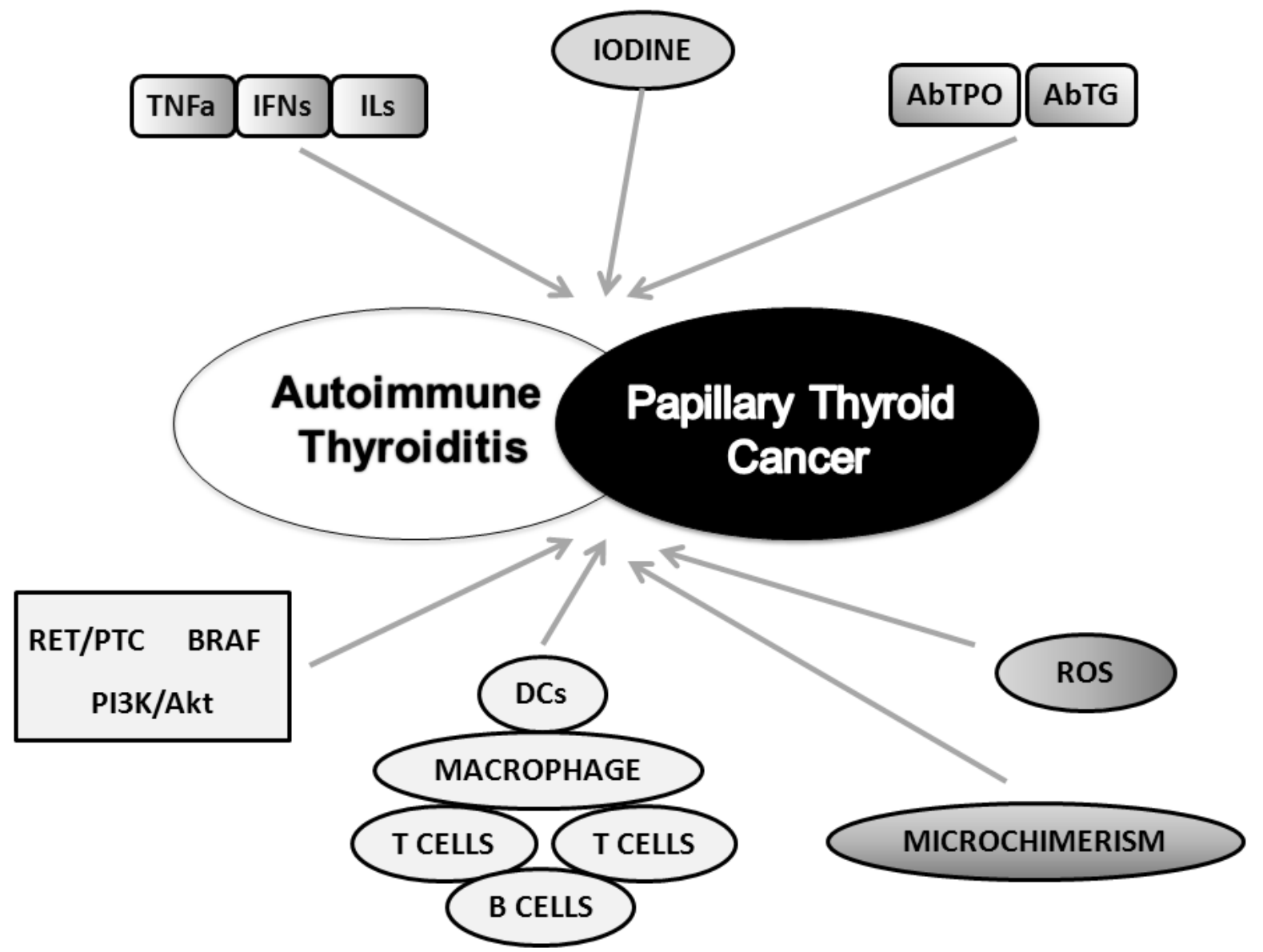

